\title{
Mesenchymal Stem Cells and Extracellular Vesicles in Osteosarcoma Pathogenesis and Therapy
}

\author{
Virinder Kaur Sarhadi ${ }^{*}+\oplus$, Ravindra Daddali ${ }^{\dagger}$ and Riitta Seppänen-Kaijansinkko \\ Department of Oral and Maxillofacial Diseases, University of Helsinki and Helsinki University Hospital, \\ 00014 Helsinki, Finland; ravindra.daddali@oulu.fi (R.D.); riitta.seppanen-kaijansinkko@helsinki.fi (R.S.-K.) \\ * Correspondence: virinder.sarhadi@helsinki.fi \\ † These authors contributed equally to this work.
}

Citation: Sarhadi, V.K.; Daddali, R.; Seppänen-Kaijansinkko, R. Mesenchymal Stem Cells and Extracellular Vesicles in Osteosarcoma Pathogenesis and Therapy. Int. J. Mol. Sci. 2021, 22, 11035. https://doi.org/10.3390/ ijms222011035

Academic Editors:

Aleksandra Klimczak,

Christian Kaltschmidt and Fritz Mertzlufft

Received: 1 September 2021

Accepted: 9 October 2021

Published: 13 October 2021

Publisher's Note: MDPI stays neutral with regard to jurisdictional claims in published maps and institutional affiliations.

Copyright: (c) 2021 by the authors. Licensee MDPI, Basel, Switzerland. This article is an open access article distributed under the terms and conditions of the Creative Commons Attribution (CC BY) license (https:// creativecommons.org/licenses/by/ $4.0 /)$.
Abstract: Osteosarcoma (OS) is an aggressive bone tumor that mainly affects children and adolescents. OS has a strong tendency to relapse and metastasize, resulting in poor prognosis and survival. The high heterogeneity and genetic complexity of OS make it challenging to identify new therapeutic targets. Mesenchymal stem cells (MSCs) are multipotent stem cells that can differentiate into adipocytes, osteoblasts, or chondroblasts. OS is thought to originate at some stage in the differentiation process of MSC to pre-osteoblast or from osteoblast precursors. MSCs contribute to OS progression by interacting with tumor cells via paracrine signaling and affect tumor cell proliferation, invasion, angiogenesis, immune response, and metastasis. Extracellular vesicles (EVs), secreted by OS cells and MSCs in the tumor microenvironment, are crucial mediators of intercellular communication, driving OS progression by transferring miRNAs/RNA and proteins to other cells. MSC-derived EVs have both pro-tumor and anti-tumor effects on OS progression. MSC-EVs can be also engineered to deliver anti-tumor cargo to the tumor site, which offers potential applications in MSC-EV-based OS treatment. In this review, we highlight the role of MSCs in OS, with a focus on EV-mediated communication between OS cells and MSCs and their role in OS pathogenesis and therapy.

Keywords: osteosarcoma; mesenchymal stem cells; extracellular vesicles; therapy

\section{Introduction}

Osteosarcoma (OS) is the most predominant primary bone cancer, commonly occurring in the long bones of children and adolescents [1]. OS is highly malignant and the major complications in OS arise due to a lack of immune response, leading to irregular bone growth and distant metastases, seen commonly in the lungs and liver. The current treatment approaches for OS are preoperative chemotherapy, surgical resection, and postoperative chemotherapy, which are effective in patients with localized OS. Conversely, patients with advanced, metastatic, and recurrent OS develop resistance to chemotherapy, which makes it difficult to treat, resulting in a poor prognosis [2]. Despite multidisciplinary treatments, there has been no change in the prognosis during the past two decades. The overall 5-year survival rate of OS patients is 65\% in the case of localized disease, while it is $20 \%$ in those with metastasis, and significantly lower in those with lung metastasis [3]. The high heterogeneity and genetic complexity of OS make it challenging to identify new therapeutic targets [4].

A thorough understanding of the tumor microenvironment (TME), especially the bone microenvironment (BME), cellular crosstalk, and the molecular mechanisms underlying tumor progression, is essential for drug design and for developing new drug molecules for OS treatment. The BME is composed of the extracellular matrix (ECM) and a variety of cells, which includes mesenchymal stem cells (MSCs), endothelial cells, macrophages, stem cells, fibroblasts, osteoblasts, osteoclasts, and osteocytes that are organized to maintain the bone rigidity and the structural as well as functional integrity of the bone niche. All these 
cells together play a crucial role in normal bone development and bone physiology and can also lead to osteosarcoma in aberrant conditions.

MSCs are multipotent, non-hematopoietic cells that have the potential to self-rejuvenate and to differentiate into different cell types, including muscle cells, hepatocytes, osteoblasts, adipocytes, chondrocytes, and stromal cells $[5,6]$. MSCs interact with cancer and other cells in the tumor microenvironment via paracrine factors and through extracellular vesicles (EVs) to support tumor growth, progression, and metastasis. Contrary to their tumorsupportive role, they have also been implicated in tumor suppression. Hence, it is vital to understand the interaction of MSCs and OS cells in the tumor microenvironment to develop new and more effective OS therapy, and to overcome drug resistance. In this review, we discuss the role of MSCs in OS and highlight the reciprocal interaction of MSCs and OS cells in modulating each other's functions, with a focus on the role of extracellular vesicles in MSC-OS communication and their therapeutic applications.

\section{Mesenchymal Stem Cells' Role in Osteosarcoma}

MSCs are an important source of adult stem cells, present in many tissues, especially in bone marrow, and adipose tissue, and are involved in tissue repair and healing. MSCs play a significant role in OS pathogenesis, from the possible cells of origin of OS to its supportive role in OS growth, progression, metastasis, and drug resistance. OS is assumed to originate at some stage in the differentiation process of MSC to pre-osteoblast and the stage of differentiation of MSC affects the OS phenotype [7,8].

\subsection{Cellular Origin of $O S$}

A better understanding of the cellular origin of OS is essential to improve the outcomes of patients. There are controversial reports about the cellular origins of OS. Some propose that OS develops from MSC; by contrast, others suggest osteoblast precursor cells as the cells of origin of OS [9].

MSCs can differentiate into osteoblasts, chondroblasts, or fibroblasts, and OS can have an osteoblastic, chondroblastic, or fibroblastic phenotype, based on the predominant cancer cell type, which suggests that MSC might be the cells of origin of OS [10,11]. There is evidence suggesting that OS originates at some point during the differentiation of MSC to pre-osteoblast $[7,8]$. The argument that MSC is a cell of origin of OS is supported by studies in murine models, where MSCs have been shown to transform into OS by genetic loss of cdkn2 locus [12]. A similar transformation of human MSCs into OS has been seen in the simultaneous knockdown of $\mathrm{Rb}$ and overexpression of c-Myc [13].

Although in vitro and in vivo genetic models support the proposition that the unusual differentiation of pre-osteoblasts may be the origin of OS, recent studies suggest that osteogenic progenitors rather than undifferentiated MSCs represent the OS cells of origin $[8,14]$. The transformation of human osteo-progenitor cells into OS is possible due to the overexpression of the MET gene [15]. Other studies have shown that the osteogenic differentiation stage of bone marrow MSCs (BM-MSCs) inflicts the phenotype of in vivo sarcoma development, implying that BM-MSC-derived osteogenic progenitors might be the cells of origin for OS [16]. Several in vivo genetic model studies support the idea that the abnormal differentiation of osteoblasts is the origin of OS cells. The debate arises from the notion that under physiological conditions, it is challenging to discriminate between MSCs and osteoblasts. While MSCs have the potential to differentiate into osteoblasts, they can transform into OS cells in a specific bone microenvironment [17].

To date, there is no conclusive evidence as to whether OS arises because of the transformation of MSCs, or osteoblastic lineage-committed cells (pre-osteoblasts). The use of advanced gene modification technology and improved gene-editing tools at the cell lineage level may help to explain the origin of OS. Understanding the cellular origin of tumors is key to improving preclinical models for testing and studying their behavior and treatment approaches, which can accelerate translational research efforts to advance outcomes for patients with OS. 


\subsection{MSCs in OS Microenvironment}

OS grows in a bone microenvironment. This is a very specialized, complex, and highly dynamic environment composed of bone cells (osteoclasts, osteoblasts, osteocytes), stromal cells (MSCs, fibroblasts), vascular cells (endothelial cells and pericytes), immune cells (macrophages, lymphocytes), and a mineralized ECM. Crosstalk between OS, bone microenvironment, and ECM involves several signals, induced by multiple cytokines, chemokines, and growth factors carried by EVs. The tumor microenvironment contributes significantly to the development of OS, and MSCs in the TME play an important role in OS growth, progression, metastasis, and drug resistance [18]. Two types of MSCs, from normal tissue and tumor tissue, can accelerate OS growth [19]. Normal-tissue MSCs are recruited to the TME and educated to undergo heterogeneous differentiation into a pro-tumor phenotype (Figure 1). Despite having similar morphological features and differentiation abilities, tumor MSCs derived from OS tissue are more potent effectors of tumor progression compared to normal tissue MSCs.

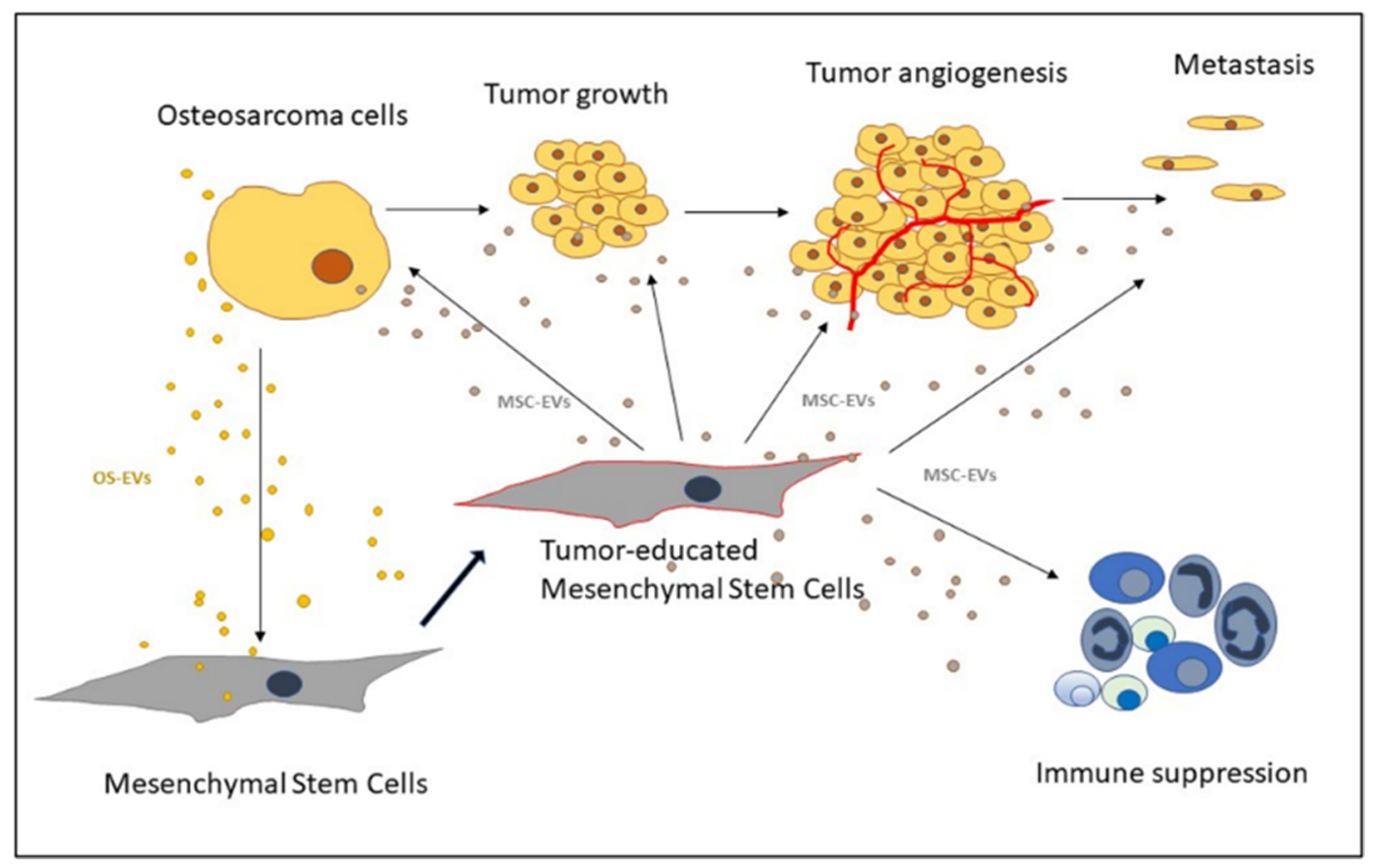

Figure 1. Schematic representation of extracellular vesicles (EVs)-mediated communication between mesenchymal stem cells and osteosarcoma cells (OS) in the OS microenvironment.

\subsection{Recruitment of MSCs to the Tumor Site}

OS cells communicate with their microenvironment via paracrine signals that induce the homing of MSCs to the tumor site, where it undergoes changes and produces inflammatory signals that affect the tumor growth, the angiogenesis process, and the immune response (Figure 1). Transforming growth factor (TGF- $\beta$ ) and stromal-derived factor (SDF1) are reported to induce the migration of MSCs towards OS cells, while MCP-1, GRO- $\alpha$, and TGF- $\beta$, in addition to effecting the chemotaxis of MSC, also induce the differentiation of MSCs into cancer-associated fibroblasts, resulting in mesenchymal-to-amoeboid transition [20].

Besides growth factors, proteases derived from ECM and chemokines play a vital role in the recruitment of MSCs at the tumor site. The activation of plasminogen, through the coupling of the Urokinase plasminogen activator and its receptor, induces the migration of MSCs to the tumor site. Moreover, higher plasminogen activity in solid tumors is associated with a greater migration of MSCs, indicating that MSCs recruitment is dependent on plasminogen activity. However, the underlying mechanism through which MSC recruitment 
is enhanced through plasminogen activation has not been fully explored [21]. MMP-1 is another ECM protease that facilitates MSC recruitment to tumor site [22].

\subsection{OS Microenvironment-Induced Changes in MSCs}

MSCs that migrate to the tumor site or are present in TME change to acquire a phenotype that promotes tumor progression and metastasis (Table 1) [23]. We have shown that OS-derived EVs bring about epigenetic changes and an increased expression of VEGF$A$ in MSCs [24]. OS cells cause the upregulation of IL-6 and VEGF in MSCs, thereby maintaining their stemness, which supports tumor growth and migration $[25,26]$. Hypoxic conditions in the tumor microenvironment induce tumor cells to switch to anaerobic glycolysis, which results in ECM acidification, which in turn helps in the conversion of normal MSCs into tumor MSCs. Avnet et al. showed that short-term acidosis-exposed MSCs induce NF- $\mathrm{kB}$ pathway activation, clonogenicity, and invasion in OS cells in coculture [27]. Moreover, acidosis was shown to induce a tissue remodeling phenotype of MSC, with an increased expression of colony-promoting factors, chemokines (CCL5, CXCL5, and CXCL1), cytokines (IL6 and IL8), and CXCR4. They further reported that the increased expression of IL6 and IL8 was seen only in normal stromal cells, but not in OS cells, which was similarly confirmed in tumor-associated stromal cells [27]. The modified MSC phenotypes can also account for the development of chemoresistance via IL6 secretion, and this mechanism holds potential for future therapeutic interventions aimed at targeting OS [27].

Table 1. Interaction of mesenchymal stem cells (MSCs) and osteosarcoma cells (OS).

\begin{tabular}{|c|c|c|c|c|}
\hline OS Signal & Effect on MSCs & MSC Signal & Effect on OS & Reference \\
\hline & & Exosomes & $\begin{array}{l}\text { Increase in COLGALT2 and } \\
\text { proliferation. }\end{array}$ & $\begin{array}{l}\text { Wang et al. } 2020 \\
\text { [28] }\end{array}$ \\
\hline & & $\mathrm{CM}^{1} /$ co-culture & $\begin{array}{l}\text { Increase in MMP2/9; STAT3 } \\
\text { activation. Increased } \\
\text { proliferation, invasion, and } \\
\text { metastasis. }\end{array}$ & $\begin{array}{l}\text { Wang et al. } 2017 \\
\text { [29] }\end{array}$ \\
\hline \multirow[t]{2}{*}{$\begin{array}{c}\text { IL-8 } \\
\text { (co-culture) }\end{array}$} & Increased IL-8. & $\begin{array}{c}\text { IL-8 } \\
\text { (co-culture) }\end{array}$ & $\begin{array}{c}\text { Increased IL-8. } \\
\text { Increased metastatic potential. }\end{array}$ & $\begin{array}{l}\text { Kawano et al. } \\
2018[30]\end{array}$ \\
\hline & & $\begin{array}{c}\text { IL-6 } \\
\mathrm{CM} / \text { co-culture }\end{array}$ & $\begin{array}{c}\text { Increase in MMP2/9; } \\
\text { JAK2/STAT3 activation. } \\
\text { Increased proliferation, } \\
\text { migration, and doxorubicin } \\
\text { resistance. }\end{array}$ & Lu et al. 2021 [31] \\
\hline $\begin{array}{l}\text { MCP-1, GRO- } \alpha, \\
\text { and TGF } \beta\end{array}$ & $\begin{array}{l}\text { Mesenchymal-to-amoeboid } \\
\text { transition. } \\
\text { Increase in MCP-1, GRO- } \alpha \text {, } \\
\text { IL-6, and IL-8 in the tumor } \\
\text { environment. }\end{array}$ & & $\begin{array}{l}\text { Increased migration, invasion, } \\
\text { and trans-endothelial migration. }\end{array}$ & $\begin{array}{l}\text { Pietrovito } \\
\text { et al. } 2018[20]\end{array}$ \\
\hline \multirow[t]{3}{*}{ OS-EVs } & $\begin{array}{l}\text { LINE-1 hypomethylation } \\
\text { increased VEGF-A. }\end{array}$ & & & $\begin{array}{l}\text { Mannerström } \\
\text { et al. } 2019 \text { [24] }\end{array}$ \\
\hline & & CM & $\begin{array}{l}\text { STAT3 activation. } \\
\text { Promote survival and drug } \\
\text { resistance. }\end{array}$ & Tu et al. 2016 [25] \\
\hline & & $\begin{array}{c}\text { MSC-EVs } \\
\text { (under stress) }\end{array}$ & $\begin{array}{l}\text { Increased migration. Apoptosis } \\
\text { resistance. }\end{array}$ & $\begin{array}{l}\text { Vallabhaneni et al. } \\
\text { 2016 [32] }\end{array}$ \\
\hline Co-culture & Increased TGF $\beta$. & $\begin{array}{l}\text { Co-culture } \\
\text { IL-6 }\end{array}$ & $\begin{array}{l}\text { Increased OS proliferation, } \\
\text { stemness \& migration. }\end{array}$ & $\begin{array}{c}\text { Cortini et al. } 2016 \\
\text { [26] }\end{array}$ \\
\hline
\end{tabular}


Table 1. Cont.

\begin{tabular}{|c|c|c|c|c|}
\hline OS Signal & Effect on MSCs & MSC Signal & Effect on OS & Reference \\
\hline & & IL-6 & $\begin{array}{l}\text { STAT3 activation. Increased } \\
\text { proliferation and metastasis. }\end{array}$ & Tu et al. 2012 [33] \\
\hline \multirow[t]{2}{*}{$\mathrm{CM} / \mathrm{TGF} \beta$} & $\begin{array}{l}\text { Increased IL-6, VEGF. } \\
\text { Inhibit osteogenic } \\
\text { differentiation. }\end{array}$ & & & Tu et al. 2014 [34] \\
\hline & & IL-8 & $\begin{array}{l}\text { CXCR1/Akt activation. } \\
\text { Promotes metastasis. }\end{array}$ & Du et al. 2018 [35] \\
\hline \multirow[t]{3}{*}{$\mathrm{EVs} / \mathrm{TGF} \beta$} & Increased IL-6. & $\begin{array}{c}\text { Tumor-educated } \\
\text { MSC }\end{array}$ & Activation of STAT3 signaling. & $\begin{array}{c}\text { Baglio et al. } 2017 \\
\text { [23] }\end{array}$ \\
\hline & & EVs & $\begin{array}{c}\text { Cell growth under hypoxia. } \\
\text { Activation of PI3K/AKT \& } \\
\text { HIF-1 } \alpha .\end{array}$ & Lin et al. 2019 [36] \\
\hline & & EVs & $\begin{array}{l}\text { Activation of Hedgehog } \\
\text { signaling. Tumor growth. }\end{array}$ & Qi et al. 2017 [37] \\
\hline
\end{tabular}

${ }^{1} \mathrm{CD}$, conditioned medium.

\subsection{Transformation of MSCs into Carcinoma-Associated Fibroblasts}

Fibroblasts, which are abundant in the stroma of TME, are considered cancer-associated fibroblasts (CAFs). CAFs mediate ECM remodeling during tumor progression and metastasis through proteolysis, crosslinking, and assembly of the ECM, which assists in malignant cell migration and invasion [38].

The conversion of MSCs to CAFs is a complex and multistep biological process involving epithelial-mesenchymal transition. The transformation of MSCs into cancerassociated fibroblasts CAFs is postulated to result from decreased $\mathrm{ECM} \mathrm{pH}$ and is further dependent on GPR68 and its downstream effectors, G-protein-coupled receptor (GPCR) and YAP. The knockdown of GPR68 or the inhibition of IL-6/STAT3 pathway in MSCs suppress in situ tumor growth and prolong lifespan after cancer grafting [39]. Recently, Lin et al., showed that treating BM-MSC with a conditioned medium from osteosarcoma cell line U2OS transforms MSCs to CAFs via increasing IL-6 expression and the phosphorylation of STAT3, which further promotes the proliferation, migration, and invasion of BM-MSCs [40]. In another in vitro study, Pietrovito et al. showed that BM-MSCs have a strong tropism towards OS cells, with cytokines such as MCP-1, GRO- $\alpha$, and TGF- $\beta 1$ being crucial factors in BM-MSC chemotaxis. Upon its recruitment to BME, BM-MSCs differentiates into cancerassociated fibroblasts, resulting in a further increase in MCP-1, GRO- $\alpha$, IL-6, and IL-8 levels in the tumor microenvironment. These cytokines were shown to promote mesenchymalto-amoeboid transition (MAT), driven by the activation of the small GTPase RhoA, in OS cells [20].

In addition to IL-6/STAT3's signaling axis in inducing BM-MSCs to CAFs transition, the Notch and Akt signaling pathway is also reported to play a crucial role in this differentiation. Interestingly, Notch signaling acts upstream of Akt signaling and thus indicates a novel mechanism of BM-MSC-to-CAF differentiation and a potential target for osteosarcoma treatment [41].

\subsection{MSCs' Role in Promoting OS Growth and Progression}

The supportive role of MSCs in OS growth is backed by many in vivo studies on animal models and by in vitro studies. When injected along with tumor-associated MSCs, OS cells develop larger tumors and more lung metastases, while blocking the paracrine signal of tumor-educated MSCs inhibits OS progression [23]. The expression of Sox2 in MSCs is reported to enhance, while its downregulation inhibits, OS progression [42]. IL-6 and CCL5 secreted by OS-associated MSCs promote OS growth and metastasis [43]. 
Both MSCs and OS cells reciprocally interact with each other and modulate the BME to favor OS growth (Table 1). OS cells secrete IL- 8 and form a signaling circuit, triggering the expression of IL-8 in MSCs, which in turn accelerates the expression of IL-8 in OS cells. The expression levels of both IL- 6 and TGF- $\beta$ are reciprocally dependent upon each other. In particular, TGF- $\beta$ enhances cell proliferation and ECM deposition and impedes the osteogenic differentiation of MSCs, to retain the cells in an undifferentiated state, which enhances the secretion of pro-tumor cytokines [34,44]. The exposure of osteosarcoma cell lines (Saos-2, MG-63) to condition media from MSCs elevates IL-6 levels, which further activates the STAT3 signaling pathway, resulting in increased tumor growth [25].

\subsection{MSCs' Role in Angiogenesis}

The cellular cross-talk between cancer cells and MSCs favors angiogenesis, through which new blood vessels form. This subsequently helps tumor progression by fulfilling the metabolic prerequisites of cancer cells. Growth factors and cytokines, such as TGF- $\beta$, MIF, IL-6, and SDF-1, which are produced in the TME and are important in the recruitment of MSCs to TME, further augment tumor growth and metastasis by promoting the neovascularization $[19,45]$ of the tumor (Figure 2). The hypoxia-inducible factor (HIF) signaling pathway activates under hypoxia and tumor cells secrete the angiogenic growth factors for endothelial cell stimulation and migrate the endothelial cells derived from MSCs. These signaling cascades help tumor-associated vascularization, which in turn supports metastasis and tumor progression [46,47]. We observed an increased expression of the angiogenic factor VEGF in adipose-derived MSCs (AD-MSCs) when these were treated with EVs derived from OS cells [24].

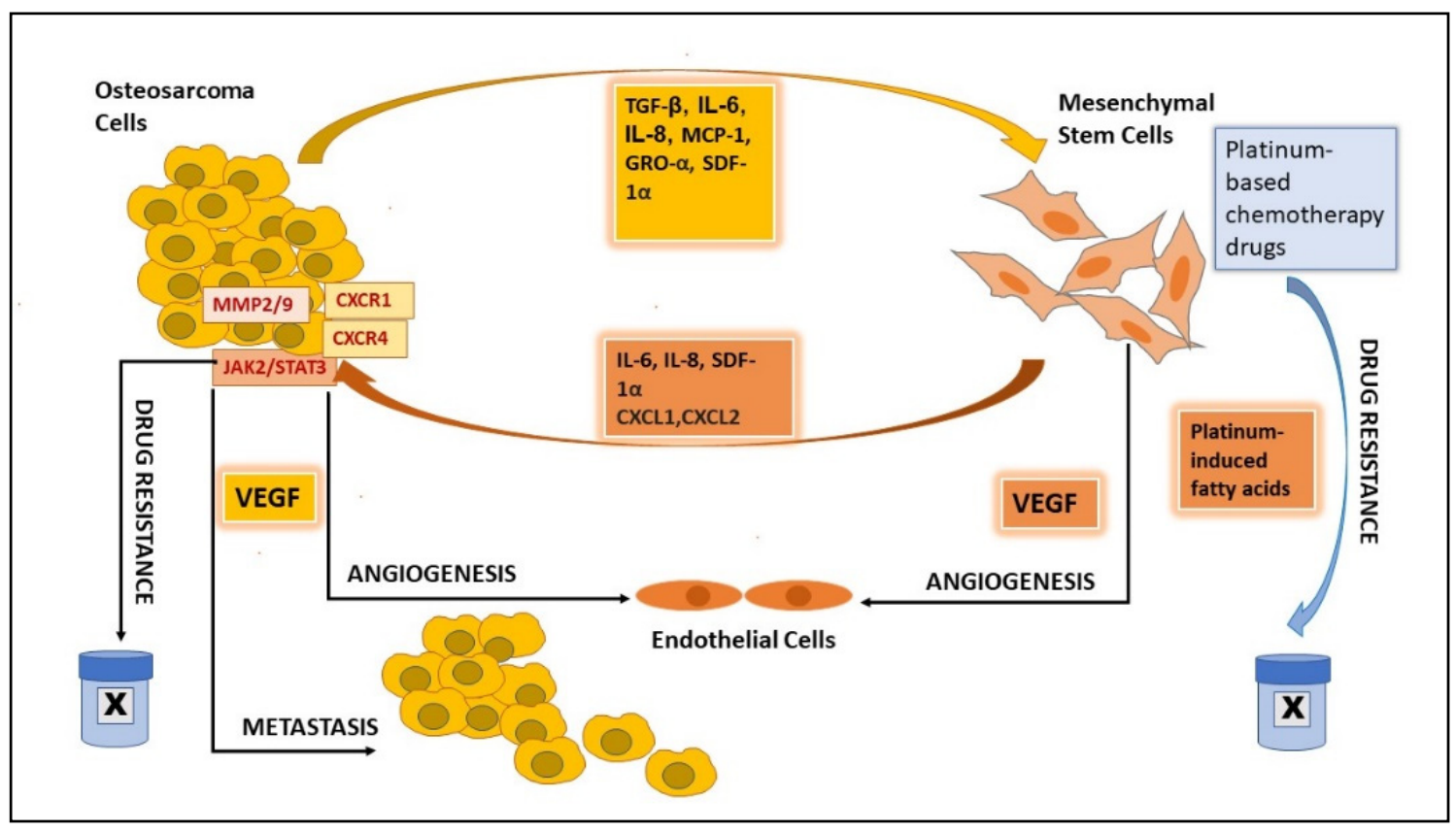

Figure 2. Graphical presentation of the role of mesenchymal stem cells in angiogenesis, metastasis, and drug resistance in osteosarcoma.

\subsection{MSCs' Role in Metastasis}

The presence of tumor-associated MSCs in the microenvironment activates the inflammatory NF-kB signaling cascade, inducing the secretion of cytokine CCL5, which assists in the migration and metastasis of OS in the late stages [47]. Du et al. suggested that MSCs can select for OS cells with high metastatic potential in vivo and claim that CXCR1 is a key target in the regulation of the pulmonary metastasis of OS cells [35]. The metastasis of osteosarcoma cells is reported to be promoted by the upregulation of CXC 
chemokine receptor 4 (CXCR4) in response to increased VEGF expression in the tumor associated MSCs (Figure 2) [48]. Pelagalli et al. showed that the exposure of OS cells to BM-MSC-conditioned medium elevates the expression level of AQP1 in OS cells and demonstrated that BM-MSCs deployed to the TME promote metastasis and invasion by upregulating AQP1 levels [49].

\subsection{MSCs' Role in Drug Resistance}

The presence of MSCs in the OS microenvironment is an important part of the OS cell survival mechanism and the development of resistance to anti-cancer drugs [50]. OS induces the expression of IL-6 in MSCs, which in turn activates STAT3 signaling in OS cells and further renders them resistant to the chemotherapeutic drugs, such as doxorubicin or cisplatin, used to treat OS (Figure 2) [25]. Besides, it promotes the survival of OS cells by protecting them from drug-induced apoptosis. The low expression of STAT3 in osteosarcoma patients reduces recurrence after surgery and chemotherapy [25]. Moreover, the inhibition of STAT 3 signaling in mouse models makes OS tumors sensitive to these drugs [51]. Likewise, an association of increased IL-6 levels with the development of chemoresistance has also been observed in several other tumors [52]. Blocking STAT3 activation might thus be a possible solution to overcome drug resistance in OS. MSCs are also reported to induce drug resistance to platinum-based chemotherapeutic drugs systemically. These drugs induce the secretion of platinum-induced polyunsaturated fatty acids (PIFAs), 12-S-hydroxy-5,8,10-heptadecatrienoic acid (12-S-HHT), and 4,7,10,13hexadecatetraenoic acid (16:4(n-3) in MSCs, leading to drug resistance [53]. The effect can be reversed by COX-1/TXAS inhibitors, such as indomethacin. Clinical trial results from a Phase 1 study using a combination of indomethacin and platinum-based chemotherapy drugs showed a moderate response and were found to be safe [54].

\subsection{MSCs as Suppressors of OS Growth}

MSCs are a double-edged sword for OS; although many studies have established the growth-promoting effects of MSCs in OS, some studies have also proven that MSCs can effectively alleviate and inhibit OS recurrence, proliferation, and metastasis. BM-MSCderived EVs containing miR-206 are reported to inhibit OS growth by targeting TRA2B [55]. The anti-tumor role of MSCs is brought about by the induction of apoptosis, the inhibition of angiogenesis, or the modulation of immune response, which, however, seems to depend upon the MSC source, the tumor site, and the content of the secretome/signaling molecules in the tumor microenvironment (reviewed in [56]).

Interestingly, MSCs suppress tumor recurrence and inhibit the growth of the residual OS cells when injected directly to the primary OS site in mice, whereas, conversely, their intravenous injection promotes lung metastasis [57]. Additionally, the concentration of injected MSCs at the tumor site dictates their effect on tumor growth, with low concentrations of AD-MSCs having an inhibitory effect and higher concentrations having a stimulating effect on tumor growth $[58,59]$. Some studies have also suggested MSCs as a suppressor of tumor angiogenesis. OS cells (Saos-2 cell line) downregulate the expression of angiogenic factors, such as CD34, PDGFA, PDGFRA, PDGFRB, and VEGF, in human AD-MSCs when co-cultured, implying that MSCs cannot differentiate in vitro under the induction of tumor cells and do not support tumor angiogenesis in vivo [60].

In another study, Wharton's jelly-derived MSCs (WJ-MSCs), when cultured with OS cells in a WJ-MSC-conditioned medium, resulted in the inhibition of OS cell proliferation and migration, with the upregulation of pro-apoptotic $B A X$ and downregulation of antiapoptotic BCL2 and SURVIVIN, as well as the upregulation of autophagy genes ATG5, ATG7, and BECLIN1 in MG-63 cells [61].

The tumor-suppressive role of MSCs also seems to depend upon their tissue source. Dental pulp MSCs (DP-MSCs) have more anti-tumor effects compared to BM-MSCs. DPMSCs exhibit increased osteogenic potential and decreased adipogenic potential, and forms a dentin pulp-like complex that is resistant to tumor transformation. The discrepancies 
responsible for the lineage commitment and tumorigenesis differences in both cells are attributed to the differences in PTEN expression, associated with hypermethylated PTEN promoter [62]. The characteristic features of DP-MSCs, including their extremely low tumorigenic potential and unusual cell fate, as well as those of WJ-MSCs, have great potential for the treatment of OS and in regenerative medicine. Investigating the mechanism of the extremely low tumorigenic potential of DP-MSCs could provide insight into their anti-tumor functions and offers a promising future clinical application.

\section{Extracellular Vesicles as Mediators of MSCs and Osteosarcoma Crosstalk}

Extracellular vesicles (EVs) are small lipid-bound vesicles released by cells that carry a heterogeneous cargo, including proteins, RNA, miRNA, other non-coding RNA, DNA, lipids, and metabolites. This cargo can be transferred to other cells and can affect their physiology, thereby playing an important role in cell-to-cell communication. EVs are classified, based on their size, into small-EV (i.e., $<200 \mathrm{~nm}$ ) and medium/large-EV (>200 nm) groups and, based on their origin/biogenesis, they are classified as exosomes (endosome origin), microvesicles (plasma membrane budding) and apoptotic bodies (apoptosis/nuclear origin) [63]. Exosomes fall mainly in the group of small EVs and are the main EVs responsible for intercellular communication.

OS cells can establish crosstalk with resident bone cells by secreting EVs in the bone microenvironment and becoming involved in regulating bone cell proliferation and differentiation, thereby promoting tumor growth [64]. In the TME, the primary tumor cells as well as stromal cells secrete EVs that mediate bidirectional cellular communication [65]. EVs can also be involved in premetastatic niche formation by promoting angiogenesis via the activation of the JAK/STAT signaling pathway $[66,67]$. The detection of tumor-specific EVs in blood circulation may serve as a diagnostic tumor marker [63].

The development of OS and tumor driving specific genetic alterations are incompletely understood so far. The alterations at the epigenetic level could be the early event occurring in the transformation of MSCs during OS development. Recently, we presented the EV-mediated intercellular crosstalk between MSC and OS, demonstrating that OS-EVs modulate the epigenetic status of MSC, through the hypomethylation of long interspersed nuclear element 1 (LINE1), whereas an opposite effect was seen in pre-osteoblasts. Our results indicate that MSCs, but not pre-osteoblasts, are susceptible to OS-EV-mediated epigenetic transformation. Furthermore, OS-derived EVs influenced the AD-MSC's expression of matrix metallopeptidase 1 (MMP1), vascular endothelial growth factor A (VEGF-A), and intercellular adhesion molecule 1 , which are related to bone microenvironment remodeling [24].

\subsection{OS-EVS}

OS cell-derived exosomes affect the tumor microenvironment by carrying microRNAs, which induce bone remodeling and tumor angiogenesis by promoting osteoclasts differentiation and bone resorption activity. The different proteins, microRNAs, and other non-coding RNAs detected in the EVs cargo derived from OS cells and MSCs that are involved in OS pathogenesis are summarized in Table 2. 
Table 2. Role of microRNA, non-coding RNA, and proteins associated with osteosarcoma (OS) and mesenchymal stem cell (MSC)-derived extracellular vesicles (EVs) in OS pathogenesis.

\begin{tabular}{|c|c|c|c|c|}
\hline Source of EVs & miRNAs/other RNAs in EVs & Proteins in EVs & Function & Reference \\
\hline OS cells & $\begin{array}{c}\text { miR-146a-5p, miR-10b-5p, } \\
\text { miR-143-3p, miR-382-5p, } \\
\text { miR-150-5p, miR-125b-5p, } \\
\text { miR-27a-3p, miR-145-5p, } \\
\text { miR-26a-5p, miR-93-5p, } \\
\text { miR-21-5p, miR-92a-3p, and } \\
\text { miR-106a-5p }\end{array}$ & $\begin{array}{l}\text { serpin-E1, serpin-F1, TIMP-1, } \\
\text { thrombospondin-1, } \\
\text { urokinase-type plasminogen } \\
\text { activator (uPA), VEGF, } \\
\text { pentraxin-3, PDGF-AA, } \\
\text { angiopoietin-2, coagulation } \\
\text { factor-III, CD26, CD105, } \\
\text { endostatin, endothelin-1, and } \\
\text { HB-EGF }\end{array}$ & Angiogenesis. & $\begin{array}{l}\text { Perut et al. } 2019 \\
\text { [68] }\end{array}$ \\
\hline OS cells \& tissue & lncRNA OIP5-AS1 & & Angiogenesis. & Li et al. 2021 [69] \\
\hline OS cells & miR-148a-3p and miR-21-5p & & TME remodeling. & $\begin{array}{l}\text { Raimondi et al. } \\
2020[64]\end{array}$ \\
\hline OS cells & & TGF $\beta$ & $\begin{array}{l}\text { Increase IL6 in } \\
\text { AD-MSCs, tumor } \\
\text { growth, STAT3 } \\
\text { activation, and lung } \\
\text { metastasis. } \\
\text { Autophagy. }\end{array}$ & $\begin{array}{c}\text { Baglio et al. 2017, } \\
\text { Tu et al. 2012, } \\
\text { Huang et al. 2020 } \\
{[23,33,70]}\end{array}$ \\
\hline BM-MSC & lncRNA MALAT1 & & $\begin{array}{l}\text { Proliferation, invasion, } \\
\text { and migration of OS } \\
\text { cells via lncRNA } \\
\text { MALAT1/miR- } \\
\text { 143/NRSN2/Wnt/ } \beta- \\
\text { Catenin } \\
\text { Axis. }\end{array}$ & Li et al. 2021 [71] \\
\hline BM-MSC & non-coding RNA PVT1 & & $\begin{array}{l}\text { OS migration by } \\
\text { upregulating ERG and } \\
\text { sponging miR-183-5p } \\
\text { in OS cells. }\end{array}$ & $\begin{array}{l}\text { Zhao et al. } 2019 \\
\text { [72] }\end{array}$ \\
\hline BM-MSC & miR-206 & & $\begin{array}{l}\text { Tumor suppression and } \\
\text { apoptosis. }\end{array}$ & $\begin{array}{c}\text { Zhang et al. } 2020 \\
\text { [55] }\end{array}$ \\
\hline BM-MSC & $\begin{array}{l}\text { microRNA-208a } \\
\text { LCP1 }\end{array}$ & & $\begin{array}{l}\text { OS cell migration \& } \\
\text { invasion. } \\
\text { OS proliferation and } \\
\text { metastasis via the } \\
\text { JAK2/STAT3 pathway. }\end{array}$ & $\begin{array}{l}\text { Qin et al. } 2020 \\
\text { [73] }\end{array}$ \\
\hline $\begin{array}{l}\text { Highly } \\
\text { metastatic OS } \\
\text { cells }\end{array}$ & & $\begin{array}{c}\text { NPM1, CCT2, CCT4, CCT6A, } \\
\text { CCT8, VIM, CLTC, COL6A2, } \\
\text { HNRNPC, PKM, ACTN4, } \\
\text { MYH10, PAICS, VCP, } \\
\text { ANXA1, ACLY }\end{array}$ & Metastasis. & $\begin{array}{l}\text { Macklin et al. } \\
2016[74]\end{array}$ \\
\hline $\begin{array}{l}\text { Engineered } \\
\text { AD-MSC }\end{array}$ & $\begin{array}{l}\text { miR-101; miR-150 } \\
\text { synthetic miR-143 }\end{array}$ & & $\begin{array}{l}\text { OS Therapy. Suppress } \\
\text { OS growth. }\end{array}$ & $\begin{array}{l}\text { Zhang et al. 2020; } \\
\text { Shimbo et al. } \\
\text { 2014; Xu et al. } \\
\text { 2020; } \\
{[75,76]}\end{array}$ \\
\hline
\end{tabular}

The impact of EVs in tumor progression and the metastatic process is exerted through both local and distant intercellular communication. Macklin et al. demonstrated the role of EVs as mediators in the transfer of migratory and invasive characteristics from OS subclones with highly metastatic traits to poorly metastatic cells. This horizontal phenotypic transfer is unidirectional, and the metastatic potential may arise through inter- 
clonal cooperation. Proteomic analysis of the EVs secreted by highly metastatic OS clonal variants has identified several proteins and G-protein coupled receptor signaling events as potential drivers of OS metastasis and novel therapeutic targets (Table 2) [74].

\subsection{MSC-EVS}

Exosomes derived from BM-MSCs are reported to promote cell proliferation, migration, and the invasion of OS cells by promoting oncogenic autophagy [70]. In a recent study, Li et al. showed that BM-MSC-derived EVs promote the proliferation, invasion, and migration of OS cells via the lncRNA MALAT1/miR-143/NRSN2/Wnt/ $\beta$-Catenin Axis. BM-MSC EVs carried MALAT1 into OS cells, increased MALAT1 and NRSN2 expressions, decreased miR-143 expression, and activated the Wnt/ $\beta$-catenin pathway in OS cells. In vivo experiments confirmed that BMSC-EVs promoted tumor growth in nude mice [71].

EVs secreted by MSCs protect OS cells from apoptosis in vitro. Vallabhaneni et al. showed that MSCs under stress (MSC cultured in serum-deprived culture medium) have pro-proliferative, anti-apoptotic, and cell migration effects on OS cells. The microRNAs from the EVs involved in this OS-MSC communication target genes associated with metabolism and metastasis, such as monocarboxylate transporters, bone morphogenic receptor type 2, fibroblast growth factor 7, matrix metalloproteinase-1, and focal adhesion kinase-1. This finding suggests that under conditions resembling nutrient-deficient tumor core tissue, the miRNA content of the EVs released from MSCs are important determinants of a supportive role in osteosarcoma growth [32]. Not surprisingly, microRNAs (miRNAs) are widely related to OS development (reviewed in [77]).

\subsection{MSC-EVs in Angiogenesis}

EVs released by MSCs also affect angiogenesis [78]. MSCs are known to promote angiogenesis under hypoxic conditions, with hypoxia-inducible factor (HIF)- $1 \alpha$ contributing significantly to this process. It has been shown that HIF- $1 \alpha$ expressing MSCs produce more EVs, can activate Notch signaling, and promote angiogenesis both in vitro and in vivo Matrigel plug studies in mice [79]. Exposing human umbilical vein endothelial cells (HUVECs) to MSC-EVs is shown to induce tube formation in vitro and to mobilize endothelial cells and increase blood flow into Matrigel plug-transplanted in mice. Moreover, MSC-EVs can transfer pro-angiogenic miRNAs, such as miR-30b, from MSCs to endothelial cells and stimulate angiogenesis [80]. On the contrary, in breast cancer cells, MSC-EVs carrying miR-100 are reported to suppress angiogenesis by decreasing the expression of VEGF, while MSC-EVs are reported to enhance VEGF expression in gastric cancer cells [81,82]. However, these contradictory findings may be dependent on the source of MSCs, the EVs' cargo, and the culture/in vivo conditions. Nevertheless, MSCs secrete EVs that carry miRNAs and proteins and, depending upon the tissue environment conditions, affect angiogenesis.

\subsection{MSC-EVs in OS Metastasis}

In addition to supporting OS growth, MSC-EVs play an important role in OS progression and metastasis. Under specific signals, MSCs are recruited to the tumor site and release factors that help in tumor cell migration and metastasis. In vitro studies have shown that the EVs secreted by MSCs under nutritional stress contain tumor-supportive miRNA, proteins, and metabolites that support cancer cell migration and apoptosis by potentially targeting metastasis-associated genes [32].

Exosomes secreted by AD-MSC promote OS cell growth, invasion, and migration by increasing the expression of COLGALT2 in OS cells in vitro and mouse models [28]. EVs derived from BM-MSC promote OS migration through transferring oncogenic non-coding RNAs and proteins. The transfer of non-coding RNA PVT1 through EVs upregulates ERG expression in OS cells by inhibiting its degradation and ubiquitination and by sponging miR-183-5p in OS cells [72]. BM-MSC-derived exosomal miR-208a promotes OS cell migration and invasion, and exosomal LCP1 promotes OS proliferation and metastasis via the JAK2/STAT3 pathway [73]. 
The activation of STAT3 in OS by IL-6 is an important mechanism in OS tumor progression and metastasis. EVs secreted by OS cells are shown to express TGF- $\beta$ on their membrane, which induces IL6 expression in MSCs. The increased IL- 6 from MSC promotes tumor growth, STAT3 activation, and lung metastasis from OS [25,29,83]. Another mechanism by which BMSC-EVs promote tumorigenesis and metastasis is the promotion of oncogenic autophagy in OS [70].

Contrary to its supporting role in OS tumor growth and metastasis, BM-MSC-derived EVs can also inhibit OS progression by targeting TRA2B via BM-MSC-derived exosomal miR-206. Both in vitro and in vivo results have shown that BM-MSC derived exosomal miR-206 can inhibit the proliferation, migration, and invasion of osteosarcoma cells and induce their apoptosis [55]

\subsection{MSC-EVs in Immune Response}

MSCs are also known to play a vital role in immunomodulation by interacting with immune cells, as well as in modulating the immune response by secreting cytokines and soluble tissue factors [84]. MSC-secreted EVs can affect the activity of immune cells by inducing the expression of anti-inflammatory cytokines while inhibiting that of proinflammatory cytokines [85]. A detailed analysis of MSC-EVs proteomes has shown that they include cytokines, chemokines, and chemokine receptors, such as IL10, HGF, LIF, CCL2, VEGFC, and CCL20, that can promote migration of MSC-EVs to injured sites and suppress inflammation [86]. MSC-EV-associated TGF- $\beta$ and IFN- $\gamma$ promote the transformation of mononuclear cells into Treg cells [87]. MSC-EVs affect the proliferation of immune cells, increase the levels of CXCL8 and MZB1 RNA, and decrease IgM in B-cells [88].

Tumor-associated macrophages (TAM) are the most common type of immune cells infiltrating OS tumors and play an important role in OS immunology. Depending upon environmental signals, macrophages can change from a tumor-suppressive M1 state to a more tumor-promoting and immune-suppressive M2 state [89]. Conditioned media from M2 macrophages increase osteoblast differentiation from MSCs [90].

EVs secreted by MSCs cultured in serum-deprived mediums and low-oxygen conditions are enriched in metabolites that have immunomodulatory effects, M2 macrophage polarization, and induction of T lymphocytes [91]. MSCs treated with conditioned media from M1 macrophages were found to promote tumor growth in a mouse model by converting tumor-associated macrophages into immunosuppressive M2 type by IL-6 secretion [92]. Moreover, M2 macrophages have been shown to increase the cancer stem cell characteristics of OS in vitro and targeting M2 tumor-associated macrophages could be useful in OS therapy [93]. The potential of the TAM targeted approach for OS treatment is increasingly accepted. Exosomes from M1 macrophages engineered to target IL-4 receptors of TAM have been shown to transform TAMs into M1 phenotypes and suppress OS growth in vivo by increasing immune response to the tumor [94].

\section{MSCs in OS Therapy}

MSCs from different tissue sources and engineered MSCs are being explored for their application in OS treatment. The unique ability of MSC to engraft and home in on tumor stroma makes them attractive targeted delivery vehicles to carry therapeutic drugs to the tumor stroma. TNF-related apoptosis-inducing ligand (TRAIL) delivered by AD-MSCs have an anti-tumorigenic effect on osteosarcoma. AD-MSC-delivered TRAIL efficiently kills OS cells, since MSCs confer a longer half-life with stable TRAIL delivery and the secretion of synergizing factors $[95,96]$. A clinical trial (NCT03298763) is underway to access the efficacy of stem-cell-expressing TRAIL (MSCTRAIL) combined with chemotherapy in metastatic non-small cell lung cancer patients. Similar clinical studies could also be possible in OS.

MSCs transduced with adenoviruses harboring the osteoprotegerin (OPG) gene, when injected into mice through the tail vein, have been shown to migrate to the tumor site and produce OPG locally, thereby inhibiting OS growth. Moreover, MSC-OPG administration is reported to cause no increase in serum OPG levels, indicating fewer side effects of systemic 
administration, and reveals the tumor suppressor role of MSC-OPG [97]. Similarly, MSCs transduced with an adenoviral vector carrying the Interleukin-12 (IL-12) gene injected into mice bearing Ewing's sarcoma have been shown to localize and produce IL-12 selectively at the tumor site, inhibiting tumor growth. Moreover, these MSCs also migrated to the lungs, spleen, and liver without harming these organs [98]. Combining the anti-tumoral effect of IL-12 and the ability of MSCs to migrate to the tumor site can be an efficient way to deliver IL-12 locally to tumors.

MSCs can also be used to deliver anti-tumor drugs. MSCs uploaded with nanoparticles and photosensitizers have been shown to trigger OS cell death in vitro upon specific photoactivation via the release of reactive oxygen species (ROS). However, antineoplastic agents, which are used in MSC delivery systems, may kill MSCs, leading to the failure of this technique [99].

MSCs also have applications in photodynamic therapy. MSCs loaded with nanoparticles (AlPcS4@FNPs) and their photoactivation have shown encouraging results in suppressing tumor growth in vitro and in vivo murine models for OS treatment. Photodynamic therapy is especially suited to patients with chemoresistant tumors or unresectable small tumors [100].

While MSCs are promising vectors for antineoplastic agent delivery and bone defect regeneration after bone sarcoma resection, there are also some concerns regarding their side effects. They can accelerate the proliferation of cancer cells, induce pulmonary metastases, and increase chemoresistance to doxorubicin and cisplatin when interacting with cancer cells in TME. However, the use of transduced MSCs to express specific anti-cancer molecules, such as TRAIL, OPG, IL-12, or the CD/5-FC prodrug selectively to the tumor site, suggest that MSCs could be suitable for delivering drugs in OS. However, more research is required to expand the engraftment efficiency of MSCs in tumors. The use of MSCs carrying oncolytic adenovirus is being tested to treat childhood tumors, including different sarcomas, and the first human clinical trial carried out using autologous bone marrow-derived MSCs carrying oncolytic virus has shown good results [101]. Preclinical testing using the same strategy, employing MSCs carrying oncolytic virus together with granulocyte-colony stimulating factor, have also shown promising results in osteosarcoma, demonstrating increased immune infiltration and reduction in tumor growth [102].

\section{MSC-EVs in OS Therapy}

EVs are known for transporting miRNAs to other cells and subsequently affecting their physiology. They are therefore being tested as a vehicle to deliver tumor-suppressive miRNA to target cancer cells. Zhang et al. revealed that AD-MSC-derived miR-101 can suppress OS via downregulation of BCL6 and proposed that AD-MSC-derived miR-101enriched EVs could represent a potential innovative therapy for metastatic OS [75].

Similarly, MSCs-derived exosomes carrying miR-150 suppresses the proliferation and migration of osteosarcoma cells by targeting IGF2BP1. Further validation of the anti-tumor effect of MSC-Exo-miR-150 in vivo indicates that it could serve as a potential therapeutic agent for OS patients. However, the efficiency and safety of MSC-Exo-miR-150 in the treatment of OS remains to be studied [103].

Another approach for miRNA delivery via MSCs for OS therapeutics is the introduction of synthetic miR-143 into MSCs, which increases the secretion of exosomal miR-143 in the conditioned medium. Exosome-formed miR-143 is easily transferred into recipient cells and suppresses the migration of OS cells [76]. Although the therapeutic application of exosome-formed miRNAs requires further in vivo studies, exosome-formed miRNAs offer great potential for the targeted delivery of miRNAs in miRNA-supplementation therapies for various diseases, including cancers such as osteosarcoma.

Exosome-based cancer therapies, especially those related to cancer vaccines and immunotherapies, have been tested in clinical trials [104]. A clinical trial of immunotherapy combining metronomic cyclophosphamide (mCTX) treatment and tumor antigen-loaded dendritic cell-derived exosomes (Dex) for treating non-small-cell lung cancer reached 
phase 2 (NCT01159288). Exosome-based cancer therapies involving engineered MSCs' exosomes are already undergoing clinical trials. A phase 1 clinical trial (NCT03608631) for treating metastatic pancreatic cancer patients with KRAS G12D mutation with MSC-derived exosomes containing KRAS G12D siRNA (iExosomes) is ongoing.

\section{Conclusions}

MSCs make a significant contribution to the development and progression of OS. MSCs and OS cells reciprocally communicate with each other via paracrine signaling, mediated by cytokines, growth factors, chemokines, and EVs. This communication induces MSC migration and its transformation into a tumor-associated phenotype that promotes angiogenesis and metastasis, and confers drug resistance. Studies on the effects of MSCs on tumor growth have produced conflicting conclusions. However, the tissue origin of MSCs, and the interaction between MSCs, OS cells, and the tumor microenvironment, seems to dictate the pro-tumorigenic or tumor-inhibiting pathways of MSC in OS. EVs aid in intercellular communication via the transport of miRNAs and proteins, and a deeper investigation into this interaction will greatly help in finding new drug targets and therapies for OS. The ability of MSCs to home in on and graft tumors provides a promising opportunity to deliver tumor-suppressive miRNAs or other noncoding RNAs, proteins, or drugs via MSC-EVs or through viral transduction. Further studies on safety, MSC tissue source, and delivery modes are needed to test the possible utility of MSC-EV-based OS therapies.

Funding: This research was funded by State funding for university-level health research, Helsinki and Uusimaa Hospital District, grant number VTR 2021232 and by Foundation for Pediatric Research.

Institutional Review Board Statement: Not applicable.

Informed Consent Statement: Not applicable.

Acknowledgments: Open access funding provided by University of Helsinki.

Conflicts of Interest: The authors declare no conflict of interest.

\section{References}

1. Mirabello, L.; Troisi, R.J.; Savage, S.A. Osteosarcoma Incidence and Survival Rates from 1973 to 2004: Data from the Surveillance, Epidemiology, and End Results Program. Cancer 2009, 115, 1531-1543. [CrossRef]

2. ESMO European Sarcoma Network Working Group. Bone Sarcomas: ESMO Clinical Practice Guidelines for Diagnosis, Treatment and Follow-Up. Ann. Oncol. 2012, 23, vii100-9. [CrossRef]

3. Broadhead, M.L.; Clark, J.C.; Myers, D.E.; Dass, C.R.; Choong, P.F. The Molecular Pathogenesis of Osteosarcoma: A Review. Sarcoma 2011, 2011, 959248. [CrossRef]

4. Kempf-Bielack, B.; Bielack, S.S.; Jurgens, H.; Branscheid, D.; Berdel, W.E.; Exner, G.U.; Gobel, U.; Helmke, K.; Jundt, G.; Kabisch, H.; et al. Osteosarcoma Relapse After Combined Modality Therapy: An Analysis of Unselected Patients in the Cooperative Osteosarcoma Study Group (COSS). J. Clin. Oncol. 2005, 23, 559-568. [CrossRef] [PubMed]

5. Bhaskar, B.; Mekala, N.K.; Baadhe, R.R.; Rao, P.S. Role of Signaling Pathways in Mesenchymal Stem Cell Differentiation. Curr. Stem Cell. Res. Ther. 2014, 9, 508-512. [CrossRef]

6. Main, H.; Munsie, M.; O'Connor, M.D. Managing the Potential and Pitfalls during Clinical Translation of Emerging Stem Cell Therapies. Clin. Transl. Med. 2014, 3, 1-10. [CrossRef] [PubMed]

7. Yang, Y.; Yang, R.; Roth, M.; Piperdi, S.; Zhang, W.; Dorfman, H.; Rao, P.; Park, A.; Tripathi, S.; Freeman, C.; et al. Genetically Transforming Human Osteoblasts to Sarcoma: Development of an Osteosarcoma Model. Genes Cancer 2017, 8, 484-494. [CrossRef] [PubMed]

8. Rubio, R.; Gutierrez-Aranda, I.; Saez-Castillo, A.I.; Labarga, A.; Rosu-Myles, M.; Gonzalez-Garcia, S.; Toribio, M.L.; Menendez, P.; Rodriguez, R. The Differentiation Stage of p53-Rb-Deficient Bone Marrow Mesenchymal Stem Cells Imposes the Phenotype of in vivo Sarcoma Development. Oncogene 2013, 32, 4970-4980. [CrossRef]

9. Mutsaers, A.J.; Walkley, C.R. Cells of Origin in Osteosarcoma: Mesenchymal Stem Cells Or Osteoblast Committed Cells? Bone 2014, 62, 56-63. [CrossRef]

10. Uccelli, A.; Moretta, L.; Pistoia, V. Mesenchymal Stem Cells in Health and Disease. Nat. Rev. Immunol. 2008, 8, 726-736. [CrossRef]

11. Jo, V.Y.; Fletcher, C.D. WHO Classification of Soft Tissue Tumours: An Update Based on the 2013 (4th) Edition. Pathology 2014, 46, 95-104. [CrossRef] 
12. Mohseny, A.B.; Szuhai, K.; Romeo, S.; Buddingh, E.P.; Briaire-de Bruijn, I.; de Jong, D.; van Pel, M.; Cleton-Jansen, A.M.; Hogendoorn, P.C. Osteosarcoma Originates from Mesenchymal Stem Cells in Consequence of Aneuploidization and Genomic Loss of Cdkn2. J. Pathol. 2009, 219, 294-305. [CrossRef]

13. Wang, J.Y.; Wu, P.K.; Chen, P.C.; Lee, C.W.; Chen, W.M.; Hung, S.C. Generation of Osteosarcomas from a Combination of Rb Silencing and C-Myc Overexpression in Human Mesenchymal Stem Cells. Stem Cells Transl. Med. 2017, 6, 512-526. [CrossRef] [PubMed]

14. Walkley, C.R.; Qudsi, R.; Sankaran, V.G.; Perry, J.A.; Gostissa, M.; Roth, S.I.; Rodda, S.J.; Snay, E.; Dunning, P.; Fahey, F.H.; et al. Conditional Mouse Osteosarcoma, Dependent on p53 Loss and Potentiated by Loss of Rb, Mimics the Human Disease. Genes Dev. 2008, 22, 1662-1676. [CrossRef] [PubMed]

15. Dani, N.; Olivero, M.; Mareschi, K.; van Duist, M.M.; Miretti, S.; Cuvertino, S.; Patane, S.; Calogero, R.; Ferracini, R.; Scotlandi, K.; et al. The MET Oncogene Transforms Human Primary Bone-Derived Cells into Osteosarcomas by Targeting Committed Osteo-Progenitors. J. Bone Miner. Res. 2012, 27, 1322-1334. [CrossRef] [PubMed]

16. Chang, X.; Ma, Z.; Zhu, G.; Lu, Y.; Yang, J. New Perspective into Mesenchymal Stem Cells: Molecular Mechanisms Regulating Osteosarcoma. J. Bone Oncol. 2021, 29, 100372. [CrossRef] [PubMed]

17. Abarrategi, A.; Tornin, J.; Martinez-Cruzado, L.; Hamilton, A.; Martinez-Campos, E.; Rodrigo, J.P.; Gonzalez, M.V.; Baldini, N.; Garcia-Castro, J.; Rodriguez, R. Osteosarcoma: Cells-of-Origin, Cancer Stem Cells, and Targeted Therapies. Stem Cells Int. 2016, 2016, 3631764. [CrossRef] [PubMed]

18. Corre, I.; Verrecchia, F.; Crenn, V.; Redini, F.; Trichet, V. The Osteosarcoma Microenvironment: A Complex but Targetable Ecosystem. Cells 2020, 9, 976. [CrossRef]

19. Sun, Z.; Wang, S.; Zhao, R.C. The Roles of Mesenchymal Stem Cells in Tumor Inflammatory Microenvironment. J. Hematol. Oncol. 2014, 7, 14. [CrossRef] [PubMed]

20. Pietrovito, L.; Leo, A.; Gori, V.; Lulli, M.; Parri, M.; Becherucci, V.; Piccini, L.; Bambi, F.; Taddei, M.L.; Chiarugi, P. Bone Marrow-Derived Mesenchymal Stem Cells Promote Invasiveness and Transendothelial Migration of Osteosarcoma Cells Via a Mesenchymal to Amoeboid Transition. Mol. Oncol. 2018, 12, 659-676. [CrossRef]

21. Gutova, M.; Najbauer, J.; Frank, R.T.; Kendall, S.E.; Gevorgyan, A.; Metz, M.Z.; Guevorkian, M.; Edmiston, M.; Zhao, D.; Glackin, C.A.; et al. Urokinase Plasminogen Activator and Urokinase Plasminogen Activator Receptor Mediate Human Stem Cell Tropism to Malignant Solid Tumors. Stem Cells 2008, 26, 1406-1413. [CrossRef] [PubMed]

22. Ho, I.A.; Yulyana, Y.; Sia, K.C.; Newman, J.P.; Guo, C.M.; Hui, K.M.; Lam, P.Y. Matrix metalloproteinase-1-mediated mesenchymal stem cell tumor tropism is dependent on crosstalk with stromal derived growth factor 1/C-X-C chemokine receptor 4 axis. FASEB J. 2014, 28, 4359-4368. [CrossRef] [PubMed]

23. Baglio, S.R.; Lagerweij, T.; Perez-Lanzon, M.; Ho, X.D.; Leveille, N.; Melo, S.A.; Cleton-Jansen, A.M.; Jordanova, E.S.; Roncuzzi, L.; Greco, M.; et al. Blocking Tumor-Educated MSC Paracrine Activity Halts Osteosarcoma Progression. Clin. Cancer Res. 2017, 23, 3721-3733. [CrossRef] [PubMed]

24. Mannerstrom, B.; Kornilov, R.; Abu-Shahba, A.G.; Chowdhury, I.M.; Sinha, S.; Seppanen-Kaijansinkko, R.; Kaur, S. Epigenetic Alterations in Mesenchymal Stem Cells by Osteosarcoma-Derived Extracellular Vesicles. Epigenetics 2019, 14, 352-364. [CrossRef] [PubMed]

25. Tu, B.; Zhu, J.; Liu, S.; Wang, L.; Fan, Q.; Hao, Y.; Fan, C.; Tang, T.T. Mesenchymal Stem Cells Promote Osteosarcoma Cell Survival and Drug Resistance through Activation of STAT3. Oncotarget 2016, 7, 48296-48308. [CrossRef]

26. Cortini, M.; Massa, A.; Avnet, S.; Bonuccelli, G.; Baldini, N. Tumor-Activated Mesenchymal Stromal Cells Promote Osteosarcoma Stemness and Migratory Potential Via IL-6 Secretion. PLoS ONE 2016, 11, e0166500. [CrossRef]

27. Avnet, S.; Di Pompo, G.; Chano, T.; Errani, C.; Ibrahim-Hashim, A.; Gillies, R.J.; Donati, D.M.; Baldini, N. Cancer-Associated Mesenchymal Stroma Fosters the Stemness of Osteosarcoma Cells in Response to Intratumoral Acidosis Via NF-kappaB Activation. Int. J. Cancer 2017, 140, 1331-1345. [CrossRef]

28. Wang, Y.; Chu, Y.; Li, K.; Zhang, G.; Guo, Z.; Wu, X.; Qiu, C.; Li, Y.; Wan, X.; Sui, J.; et al. Exosomes Secreted by Adipose-Derived Mesenchymal Stem Cells Foster Metastasis and Osteosarcoma Proliferation by Increasing COLGALT2 Expression. Front. Cell. Dev. Biol. 2020, 8, 353. [CrossRef]

29. Wang, Y.; Chu, Y.; Yue, B.; Ma, X.; Zhang, G.; Xiang, H.; Liu, Y.; Wang, T.; Wu, X.; Chen, B. Adipose-Derived Mesenchymal Stem Cells Promote Osteosarcoma Proliferation and Metastasis by Activating the STAT3 Pathway. Oncotarget 2017, 8, 23803-23816. [CrossRef]

30. Kawano, M.; Tanaka, K.; Itonaga, I.; Iwasaki, T.; Tsumura, H. Interaction between Human Osteosarcoma and Mesenchymal Stem Cells Via an Interleukin-8 Signaling Loop in the Tumor Microenvironment. Cell. Commun. Signal. 2018, 16, 13. [CrossRef]

31. Lu, M.; Xie, K.; Lu, X.; Lu, L.; Shi, Y.; Tang, Y. Notoginsenoside R1 Counteracts Mesenchymal Stem Cell-Evoked Oncogenesis and Doxorubicin Resistance in Osteosarcoma Cells by Blocking IL-6 Secretion-Induced JAK2/STAT3 Signaling. Invest. New Drugs 2021, 39, 416-425. [CrossRef]

32. Vallabhaneni, K.C.; Hassler, M.Y.; Abraham, A.; Whitt, J.; Mo, Y.Y.; Atfi, A.; Pochampally, R. Mesenchymal Stem/Stromal Cells Under Stress Increase Osteosarcoma Migration and Apoptosis Resistance Via Extracellular Vesicle Mediated Communication. PLoS ONE 2016, 11, e0166027. [CrossRef] [PubMed]

33. Tu, B.; Du, L.; Fan, Q.M.; Tang, Z.; Tang, T.T. STAT3 Activation by IL-6 from Mesenchymal Stem Cells Promotes the Proliferation and Metastasis of Osteosarcoma. Cancer Lett. 2012, 325, 80-88. [CrossRef] [PubMed] 
34. Tu, B.; Peng, Z.X.; Fan, Q.M.; Du, L.; Yan, W.; Tang, T.T. Osteosarcoma Cells Promote the Production of Pro-Tumor Cytokines in Mesenchymal Stem Cells by Inhibiting their Osteogenic Differentiation through the TGF-Beta/Smad2/3 Pathway. Exp. Cell Res. 2014, 320, 164-173. [CrossRef] [PubMed]

35. Du, L.; Han, X.G.; Tu, B.; Wang, M.Q.; Qiao, H.; Zhang, S.H.; Fan, Q.M.; Tang, T.T. CXCR1/Akt Signaling Activation Induced by Mesenchymal Stem Cell-Derived IL-8 Promotes Osteosarcoma Cell Anoikis Resistance and Pulmonary Metastasis. Cell. Death Dis. 2018, 9, 714. [CrossRef] [PubMed]

36. Lin, S.; Zhu, B.; Huang, G.; Zeng, Q.; Wang, C. Microvesicles Derived from Human Bone Marrow Mesenchymal Stem Cells Promote U2OS Cell Growth Under Hypoxia: The Role of PI3K/AKT and HIF-1alpha. Hum. Cell 2019, 32, 64-74. [CrossRef] [PubMed]

37. Qi, J.; Zhou, Y.; Jiao, Z.; Wang, X.; Zhao, Y.; Li, Y.; Chen, H.; Yang, L.; Zhu, H.; Li, Y. Exosomes Derived from Human Bone Marrow Mesenchymal Stem Cells Promote Tumor Growth through Hedgehog Signaling Pathway. Cell. Physiol. Biochem. 2017, 42, 2242-2254. [CrossRef]

38. Liu, T.; Zhou, L.; Li, D.; Andl, T.; Zhang, Y. Cancer-Associated Fibroblasts Build and Secure the Tumor Microenvironment. Front. Cell. Dev. Biol. 2019, 7,60.

39. Zhu, H.; Guo, S.; Zhang, Y.; Yin, J.; Yin, W.; Tao, S.; Wang, Y.; Zhang, C. Proton-Sensing GPCR-YAP Signalling Promotes Cancer-Associated Fibroblast Activation of Mesenchymal Stem Cells. Int. J. Biol. Sci. 2016, 12, 389-396. [CrossRef]

40. Lin, L.; Huang, K.; Guo, W.; Zhou, C.; Wang, G.; Zhao, Q. Conditioned Medium of the Osteosarcoma Cell Line U2OS Induces hBMSCs to Exhibit Characteristics of Carcinoma-Associated Fibroblasts Via Activation of IL-6/STAT3 Signalling. J. Biochem. 2020, 168, 265-271. [CrossRef]

41. Wang, Y.M.; Wang, W.; Qiu, E.D. Osteosarcoma Cells Induce Differentiation of Mesenchymal Stem Cells into Cancer Associated Fibroblasts through Notch and Akt Signaling Pathway. Int. J. Clin. Exp. Pathol. 2017, 10, 8479-8486.

42. Maurizi, G.; Verma, N.; Gadi, A.; Mansukhani, A.; Basilico, C. Sox2 is Required for Tumor Development and Cancer Cell Proliferation in Osteosarcoma. Oncogene 2018, 37, 4626-4632. [CrossRef]

43. Xu, W.T.; Bian, Z.Y.; Fan, Q.M.; Li, G.; Tang, T.T. Human Mesenchymal Stem Cells (hMSCs) Target Osteosarcoma and Promote its Growth and Pulmonary Metastasis. Cancer Lett. 2009, 281, 32-41. [CrossRef] [PubMed]

44. Zhou, S. TGF-Beta Regulates Beta-Catenin Signaling and Osteoblast Differentiation in Human Mesenchymal Stem Cells. J. Cell. Biochem. 2011, 112, 1651-1660. [CrossRef] [PubMed]

45. Li, G.C.; Zhang, H.W.; Zhao, Q.C.; Sun, L.I.; Yang, J.J.; Hong, L.; Feng, F.; Cai, L. Mesenchymal stem cells promote tumor angiogenesis via the action of transforming growth factor $\beta 1$. Oncol. Lett. 2016, 11, 1089-1094. [CrossRef] [PubMed]

46. Batlle, R.; Andrés, E.; Gonzalez, L.; Llonch, E.; Igea, A.; Gutierrez-Prat, N.; Berenguer-Llergo, A.; Nebreda, A.R. Regulation of tumor angiogenesis and mesenchymal-endothelial transition by $\mathrm{p} 38 \alpha$ through TGF- $\beta$ and JNK signaling. Nat. Commun. 2019, 10, 3071. [CrossRef]

47. Chaturvedi, P.; Gilkes, D.M.; Wong, C.C.; Kshitiz, J.; Luo, W.; Zhang, H.; Wei, H.; Takano, N.; Schito, L.; Levchenko, A.; et al. Hypoxia-Inducible Factor-Dependent Breast Cancer-Mesenchymal Stem Cell Bidirectional Signaling Promotes Metastasis. J. Clin. Invest. 2013, 123, 189-205. [CrossRef] [PubMed]

48. Zhang, P.; Dong, L.; Yan, K.; Long, H.; Yang, T.T.; Dong, M.Q.; Zhou, Y.; Fan, Q.Y.; Ma, B.A. CXCR4-Mediated Osteosarcoma Growth and Pulmonary Metastasis is Promoted by Mesenchymal Stem Cells through VEGF. Oncol. Rep. 2013, 30, $1753-1761$. [CrossRef]

49. Pelagalli, A.; Nardelli, A.; Fontanella, R.; Zannetti, A. Inhibition of AQP1 Hampers Osteosarcoma and Hepatocellular Carcinoma Progression Mediated by Bone Marrow-Derived Mesenchymal Stem Cells. Int. J. Mol. Sci. 2016, 17, 1102. [CrossRef]

50. Birru, B.; Durthi, C.P.; Kacham, S.; Pola, M.; Rajulapati, S.B.; Parcha, S.R.; Kamal, M.A. Stem Cells in Tumour Microenvironment Aid in Prolonged Survival Rate of Cancer Cells and Developed Drug Resistance: Major Challenge in Osteosarcoma Treatment. Curr. Drug Metab. 2020, 21, 44-52. [CrossRef] [PubMed]

51. Wang, Z.; Wang, C.; Zuo, D.; Zhang, T.; Yin, F.; Zhou, Z.; Wang, H.; Xu, J.; Mao, M.; Wang, G.; et al. Attenuation of STAT3 Phosphorylation Promotes Apoptosis and Chemosensitivity in Human Osteosarcoma Induced by Raddeanin A. Int. J. Biol. Sci. 2019, 15, 668-679. [CrossRef]

52. Bharti, R.; Dey, G.; Mandal, M. Cancer Development, Chemoresistance, Epithelial to Mesenchymal Transition and Stem Cells: A Snapshot of IL-6 Mediated Involvement. Cancer Lett. 2016, 375, 51-61. [CrossRef]

53. Roodhart, J.M.; Daenen, L.G.; Stigter, E.C.; Prins, H.J.; Gerrits, J.; Houthuijzen, J.M.; Gerritsen, M.G.; Schipper, H.S.; Backer, M.J.; van Amersfoort, M.; et al. Mesenchymal stem cells induce resistance to chemotherapy through the release of platinum-induced fatty acids. Cancer Cell 2011, 20, 370-383. [CrossRef]

54. van der Velden, D.L.; Cirkel, G.A.; Houthuijzen, J.M.; van Werkhoven, E.; Roodhart, J.M.L.; Daenen, L.G.M.; Kaing, S.; Gerrits, J.; Verhoeven-Duif, N.M.; Grootscholten, C.; et al. Phase I study of combined indomethacin and platinum-based chemotherapy to reduce platinum-induced fatty acids. Cancer Chemother Pharmacol. 2018, 81, 911-921. [CrossRef] [PubMed]

55. Zhang, H.; Wang, J.; Ren, T.; Huang, Y.; Liang, X.; Yu, Y.; Wang, W.; Niu, J.; Guo, W. Bone Marrow Mesenchymal Stem Cell-Derived Exosomal miR-206 Inhibits Osteosarcoma Progression by Targeting TRA2B. Cancer Lett. 2020, 490, 54-65. [CrossRef] [PubMed]

56. Eiro, N.; Fraile, M.; Fernandez-Francos, S.; Sanchez, R.; Costa, L.A.; Vizoso, F.J. Importance of the Origin of Mesenchymal (Stem) Stromal Cells in Cancer Biology: "Alliance" or "War" in Intercellular Signals. Cell Biosci. 2021, 11, 109. [CrossRef] [PubMed] 
57. Aanstoos, M.E.; Regan, D.P.; Rose, R.J.; Chubb, L.S.; Ehrhart, N.P. Do Mesenchymal Stromal Cells Influence Microscopic Residual Or Metastatic Osteosarcoma in a Murine Model? Clin. Orthop. Relat. Res. 2016, 474, 707-715. [CrossRef]

58. Lee, S.W.; Jeon, T.J.; Biswal, S. Effect of Local Treatment with Adipose Tissue-Derived Mesenchymal Stem Cells in the Early Tumorigenesis of Osteosarcoma. Oncol. Rep. 2015, 33, 1381-1387. [CrossRef]

59. Ghannam, S.; Bouffi, C.; Djouad, F.; Jorgensen, C.; Noel, D. Immunosuppression by Mesenchymal Stem Cells: Mechanisms and Clinical Applications. Stem Cell. Res. Ther. 2010, 1, 2. [CrossRef]

60. Paino, F.; La Noce, M.; Di Nucci, D.; Nicoletti, G.F.; Salzillo, R.; De Rosa, A.; Ferraro, G.A.; Papaccio, G.; Desiderio, V.; Tirino, V. Human Adipose Stem Cell Differentiation is Highly Affected by Cancer Cells both in vitro and in vivo: Implication for Autologous Fat Grafting. Cell. Death Dis. 2017, 8, e2568. [CrossRef]

61. Gauthaman, K.; Yee, F.C.; Cheyyatraivendran, S.; Biswas, A.; Choolani, M.; Bongso, A. Human Umbilical Cord Wharton's Jelly Stem Cell (hWJSC) Extracts Inhibit Cancer Cell Growth in vitro. J. Cell. Biochem. 2012, 113, 2027-2039. [CrossRef] [PubMed]

62. Shen, W.C.; Lai, Y.C.; Li, L.H.; Liao, K.; Lai, H.C.; Kao, S.Y.; Wang, J.; Chuong, C.M.; Hung, S.C. Methylation and PTEN Activation in Dental Pulp Mesenchymal Stem Cells Promotes Osteogenesis and Reduces Oncogenesis. Nat. Commun. 2019, $10,2226$. [CrossRef] [PubMed]

63. Kalluri, R.; LeBleu, V.S. The Biology, Function, and Biomedical Applications of Exosomes. Science 2020, 367, 977. [CrossRef] [PubMed]

64. Raimondi, L.; De Luca, A.; Gallo, A.; Costa, V.; Russelli, G.; Cuscino, N.; Manno, M.; Raccosta, S.; Carina, V.; Bellavia, D.; et al. Osteosarcoma Cell-Derived Exosomes Affect Tumor Microenvironment by Specific Packaging of microRNAs. Carcinogenesis 2020, 41, 666-677. [CrossRef]

65. Wortzel, I.; Dror, S.; Kenific, C.M.; Lyden, D. Exosome-Mediated Metastasis: Communication from a Distance. Dev. Cell 2019, 49, 347-360. [CrossRef]

66. Lobb, R.J.; Lima, L.G.; Moller, A. Exosomes: Key Mediators of Metastasis and Pre-Metastatic Niche Formation. Semin. Cell Dev. Biol. 2017, 67, 3-10. [CrossRef]

67. Zhuang, G.; Wu, X.; Jiang, Z.; Kasman, I.; Yao, J.; Guan, Y.; Oeh, J.; Modrusan, Z.; Bais, C.; Sampath, D.; et al. Tumour-Secreted miR-9 Promotes Endothelial Cell Migration and Angiogenesis by Activating the JAK-STAT Pathway. EMBO J. 2012, 31, 3513-3523. [CrossRef]

68. Perut, F.; Roncuzzi, L.; Zini, N.; Massa, A.; Baldini, N. Extracellular Nanovesicles Secreted by Human Osteosarcoma Cells Promote Angiogenesis. Cancers 2019, 11, 779. [CrossRef]

69. Li, Y.; Lin, S.; Xie, X.; Zhu, H.; Fan, T.; Wang, S. Highly Enriched Exosomal lncRNA OIP5-AS1 Regulates Osteosarcoma Tumor Angiogenesis and Autophagy through miR-153 and ATG5. Am. J. Transl. Res. 2021, 13, 4211-4223.

70. Huang, Y.; Liu, W.; He, B.; Wang, L.; Zhang, F.; Shu, H.; Sun, L. Exosomes Derived from Bone Marrow Mesenchymal Stem Cells Promote Osteosarcoma Development by Activating Oncogenic Autophagy. J. Bone Oncol. 2020, 21, 100280. [CrossRef]

71. Li, F.; Chen, X.; Shang, C.; Ying, Q.; Zhou, X.; Zhu, R.; Lu, H.; Hao, X.; Dong, Q.; Jiang, Z. Bone Marrow Mesenchymal Stem Cells-Derived Extracellular Vesicles Promote Proliferation, Invasion and Migration of Osteosarcoma Cells via the lncRNA MALAT1/miR-143/NRSN2/Wnt/Beta-Catenin Axis. Onco Targets Ther. 2021, 14, 737-749. [CrossRef]

72. Zhao, W.; Qin, P.; Zhang, D.; Cui, X.; Gao, J.; Yu, Z.; Chai, Y.; Wang, J.; Li, J. Long Non-Coding RNA PVT1 Encapsulated in Bone Marrow Mesenchymal Stem Cell-Derived Exosomes Promotes Osteosarcoma Growth and Metastasis by Stabilizing ERG and Sponging miR-183-5p. Aging 2019, 11, 9581-9596. [CrossRef]

73. Qin, F.; Tang, H.; Zhang, Y.; Zhang, Z.; Huang, P.; Zhu, J. Bone Marrow-Derived Mesenchymal Stem Cell-Derived Exosomal microRNA-208a Promotes Osteosarcoma Cell Proliferation, Migration, and Invasion. J. Cell. Physiol. 2020, 235, 4734-4745. [CrossRef]

74. Macklin, R.; Wang, H.; Loo, D.; Martin, S.; Cumming, A.; Cai, N.; Lane, R.; Ponce, N.S.; Topkas, E.; Inder, K.; et al. Extracellular Vesicles Secreted by Highly Metastatic Clonal Variants of Osteosarcoma Preferentially Localize to the Lungs and Induce Metastatic Behaviour in Poorly Metastatic Clones. Oncotarget 2016, 7, 43570-43587. [CrossRef] [PubMed]

75. Zhang, K.; Dong, C.; Chen, M.; Yang, T.; Wang, X.; Gao, Y.; Wang, L.; Wen, Y.; Chen, G.; Wang, X.; et al. Extracellular Vesicle-Mediated Delivery of miR-101 Inhibits Lung Metastasis in Osteosarcoma. Theranostics 2020, 10, 411-425. [CrossRef] [PubMed]

76. Shimbo, K.; Miyaki, S.; Ishitobi, H.; Kato, Y.; Kubo, T.; Shimose, S.; Ochi, M. Exosome-Formed Synthetic microRNA-143 is Transferred to Osteosarcoma Cells and Inhibits their Migration. Biochem. Biophys. Res. Commun. 2014, 445, $381-387$.

77. Kobayashi, E.; Hornicek, F.J.; Duan, Z. MicroRNA Involvement in Osteosarcoma. Sarcoma 2012, 2012, 359739. [CrossRef]

78. Alcayaga-Miranda, F.; Varas-Godoy, M.; Khoury, M. Harnessing the Angiogenic Potential of Stem Cell-Derived Exosomes for Vascular Regeneration. Stem Cells Int. 2016, 2016, 3409169. [CrossRef] [PubMed]

79. Gonzalez-King, H.; Garcia, N.A.; Ontoria-Oviedo, I.; Ciria, M.; Montero, J.A.; Sepulveda, P. Hypoxia Inducible Factor-1alpha Potentiates Jagged 1-Mediated Angiogenesis by Mesenchymal Stem Cell-Derived Exosomes. Stem Cells 2017, 35, 1747-1759. [CrossRef] [PubMed]

80. Gong, M.; Yu, B.; Wang, J.; Wang, Y.; Liu, M.; Paul, C.; Millard, R.W.; Xiao, D.S.; Ashraf, M.; Xu, M. Mesenchymal Stem Cells Release Exosomes that Transfer miRNAs to Endothelial Cells and Promote Angiogenesis. Oncotarget 2017, 8, 45200-45212. [CrossRef] [PubMed] 
81. Lee, J.K.; Park, S.R.; Jung, B.K.; Jeon, Y.K.; Lee, Y.S.; Kim, M.K.; Kim, Y.G.; Jang, J.Y.; Kim, C.W. Exosomes Derived from Mesenchymal Stem Cells Suppress Angiogenesis by Down-Regulating VEGF Expression in Breast Cancer Cells. PLoS ONE 2013, $8, \mathrm{e} 84256$.

82. Zhu, W.; Huang, L.; Li, Y.; Zhang, X.; Gu, J.; Yan, Y.; Xu, X.; Wang, M.; Qian, H.; Xu, W. Exosomes Derived from Human Bone Marrow Mesenchymal Stem Cells Promote Tumor Growth in vivo. Cancer Lett. 2012, 315, 28-37. [CrossRef]

83. Bian, Z.Y.; Fan, Q.M.; Li, G.; Xu, W.T.; Tang, T.T. Human Mesenchymal Stem Cells Promote Growth of Osteosarcoma: Involvement of Interleukin-6 in the Interaction between Human Mesenchymal Stem Cells and Saos-2. Cancer Sci. 2010, 101, $2554-2560$. [CrossRef]

84. Le Blanc, K.; Ringden, O. Immunobiology of Human Mesenchymal Stem Cells and Future use in Hematopoietic Stem Cell Transplantation. Biol. Blood Marrow Transplant. 2005, 11, 321-334. [CrossRef] [PubMed]

85. Zhang, B.; Yin, Y.; Lai, R.C.; Tan, S.S.; Choo, A.B.; Lim, S.K. Mesenchymal Stem Cells Secrete Immunologically Active Exosomes. Stem Cells Dev. 2014, 23, 1233-1244. [CrossRef]

86. Mardpour, S.; Hamidieh, A.A.; Taleahmad, S.; Sharifzad, F.; Taghikhani, A.; Baharvand, H. Interaction between Mesenchymal Stromal Cell-Derived Extracellular Vesicles and Immune Cells by Distinct Protein Content. J. Cell. Physiol. 2019, 234, 8249-8258. [CrossRef] [PubMed]

87. Zhang, Q.; Fu, L.; Liang, Y.; Guo, Z.; Wang, L.; Ma, C.; Wang, H. Exosomes Originating from MSCs Stimulated with TGF-Beta and IFN-Gamma Promote Treg Differentiation. J. Cell. Physiol. 2018, 233, 6832-6840. [CrossRef] [PubMed]

88. Khare, D.; Or, R.; Resnick, I.; Barkatz, C.; Almogi-Hazan, O.; Avni, B. Mesenchymal Stromal Cell-Derived Exosomes Affect mRNA Expression and Function of B-Lymphocytes. Front. Immunol. 2018, 9, 3053. [CrossRef] [PubMed]

89. Luo, Z.W.; Liu, P.P.; Wang, Z.X.; Chen, C.Y.; Xie, H. Macrophages in Osteosarcoma Immune Microenvironment: Implications for Immunotherapy. Front. Oncol. 2020, 10, 586580. [CrossRef]

90. Cersosimo, F.; Lonardi, S.; Bernardini, G.; Telfer, B.; Mandelli, G.E.; Santucci, A.; Vermi, W.; Giurisato, E. Tumor-Associated Macrophages in Osteosarcoma: From Mechanisms to Therapy. Int. J. Mol. Sci. 2020, 21, 5207. [CrossRef] [PubMed]

91. Showalter, M.R.; Wancewicz, B.; Fiehn, O.; Archard, J.A.; Clayton, S.; Wagner, J.; Deng, P.; Halmai, J.; Fink, K.D.; Bauer, G.; et al. Primed Mesenchymal Stem Cells Package Exosomes with Metabolites Associated with Immunomodulation. Biochem. Biophys. Res. Commun. 2019, 512, 729-735. [CrossRef] [PubMed]

92. Jia, X.H.; Feng, G.W.; Wang, Z.L.; Du, Y.; Shen, C.; Hui, H.; Peng, D.; Li, Z.J.; Kong, D.L.; Tian, J. Activation of mesenchymal stem cells by macrophages promotes tumor progression through immune suppressive effects. Oncotarget 2016, 12, 20934-20944. [CrossRef]

93. Shao, X.J.; Xiang, S.F.; Chen, Y.Q.; Zhang, N.; Cao, J.; Zhu, H.; Yang, B.; Zhou, Q.; Ying, M.D.; He, Q.J. Inhibition of M2-like macrophages by all-trans retinoic acid prevents cancer initiation and stemness in osteosarcoma cells. Acta. Pharmacol. Sin. 2019, 40, 1343-1350. [CrossRef] [PubMed]

94. Gunassekaran, G.R.; Poongkavithai Vadevoo, S.M.; Baek, M.C.; Lee, B. M1 macrophage exosomes engineered to foster M1 polarization and target the IL-4 receptor inhibit tumor growth by reprogramming tumor-associated macrophages into M1-like macrophages. Biomaterials 2021, 278, 121137. [CrossRef] [PubMed]

95. Grisendi, G.; Spano, C.; D’souza, N.; Rasini, V.; Veronesi, E.; Prapa, M.; Petrachi, T.; Piccinno, S.; Rossignoli, F.; Burns, J.S.; et al. Mesenchymal Progenitors Expressing TRAIL Induce Apoptosis in Sarcomas. Stem Cells 2015, 33, 859-869. [CrossRef]

96. Gamie, Z.; Kapriniotis, K.; Papanikolaou, D.; Haagensen, E.; Da Conceicao Ribeiro, R.; Dalgarno, K.; Krippner-Heidenreich, A.; Gerrand, C.; Tsiridis, E.; Rankin, K.S. TNF-Related Apoptosis-Inducing Ligand (TRAIL) for Bone Sarcoma Treatment: Pre-Clinical and Clinical Data. Cancer Lett. 2017, 409, 66-80. [CrossRef]

97. Qiao, B.; Shui, W.; Cai, L.; Guo, S.; Jiang, D. Human Mesenchymal Stem Cells as Delivery of Osteoprotegerin Gene: Homing and Therapeutic Effect for Osteosarcoma. Drug Des. Devel. Ther. 2015, 9, 969-976. [CrossRef] [PubMed]

98. Duan, X.; Guan, H.; Cao, Y.; Kleinerman, E.S. Murine Bone Marrow-Derived Mesenchymal Stem Cells as Vehicles for Interleukin12 Gene Delivery into Ewing Sarcoma Tumors. Cancer 2009, 115, 13-22. [CrossRef]

99. Duchi, S.; Sotgiu, G.; Lucarelli, E.; Ballestri, M.; Dozza, B.; Santi, S.; Guerrini, A.; Dambruoso, P.; Giannini, S.; Donati, D.; et al Mesenchymal Stem Cells as Delivery Vehicle of Porphyrin Loaded Nanoparticles: Effective Photoinduced in vitro Killing of Osteosarcoma. J. Control. Release 2013, 168, 225-237. [CrossRef]

100. Lenna, S.; Bellotti, C.; Duchi, S.; Martella, E.; Columbaro, M.; Dozza, B.; Ballestri, M.; Guerrini, A.; Sotgiu, G.; Frisoni, T.; et al. Mesenchymal stromal cells mediated delivery of photoactive nanoparticles inhibits osteosarcoma growth in vitro and in a murine in vivo ectopic model. J. Exp. Clin. Cancer Res. 2020, 39, 40. [CrossRef]

101. Ruano, D.; López-Martín, J.A.; Moreno, L.; Lassaletta, Á.; Bautista, F.; Andión, M.; Hernández, C.; González-Murillo, Á.; Melen, G.; Alemany, R.; et al. First-in-Human, First-in-Child Trial of Autologous MSCs Carrying the Oncolytic Virus Icovir-5 in Patients with Advanced Tumors. Mol. Ther. 2020, 28, 1033-1042. [CrossRef] [PubMed]

102. Morales-Molina, A.; Gambera, S.; Leo, A.; García-Castro, J. Combination immunotherapy using G-CSF and oncolytic virotherapy reduces tumor growth in osteosarcoma. J. Immunother. Cancer 2021, 9, e001703. [CrossRef] [PubMed] 
103. Xu, Z.; Zhou, X.; Wu, J.; Cui, X.; Wang, M.; Wang, X.; Gao, Z. Mesenchymal stem cell-derived exosomes carrying microRNA-150 suppresses the proliferation and migration of osteosarcoma cells via targeting IGF2BP1. Transl. Cancer Res. 2020, 9, $5323-5335$. [CrossRef]

104. Xu, Z.; Zeng, S.; Gong, Z.; Yan, Y. Exosome-based immunotherapy: A promising approach for cancer treatment. Mol. Cancer 2020, 19, 160. [CrossRef] 